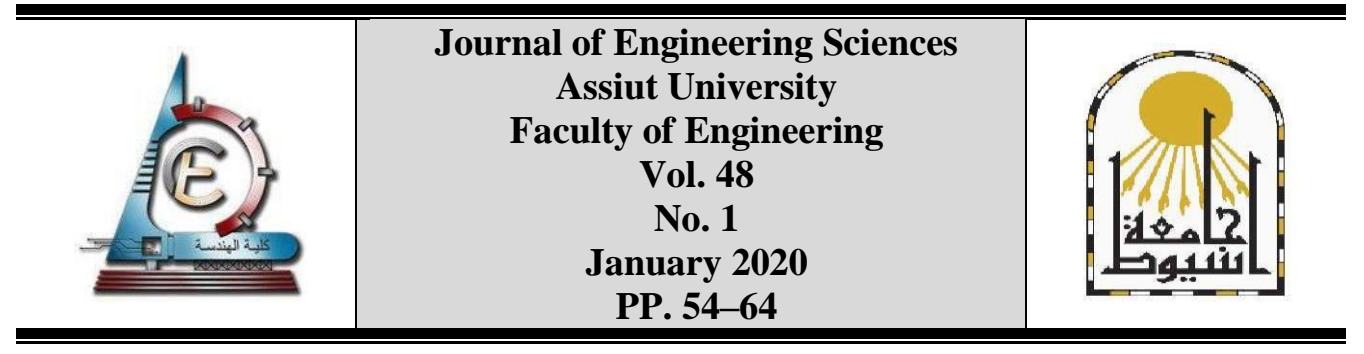

\title{
DETERMINATION OF BENCH BLAST DESIGN PARAMETERS FOR LIMESTONE QUARRY AT GABLE OKHEIDER, AL AIN EL SUKHNA - WEST OF GULF OF SUEZ, EGYPT
}

\author{
Mostafa T. Mohamed ${ }^{1}$, Mahran $\mathrm{T}^{2}$ and Youssif Sh. Mohamed ${ }^{3}$ \\ ${ }^{1}$ Mining and Metallurgical Eng. Dept., College of Eng. Assuit Univ. \\ ${ }^{2}$ Geology. Geo. Dept., College of science. Sohag Univ. \\ ${ }^{3}$ quarries and raw materials Dept., El -Sewedy cement Co.
}

Received 14 October 2019; Accepted 8 December 2019

\begin{abstract}
Bench design geometry parameters are considered the important issue of rock extraction. It directly has influences on rock extraction on all surface mines and quarries operation. This paper discuss the bench height calculation according to three important considerations; the stability of slope faces, the safety of the work place and the efficiency of the work place, besides the calculation of optimum working bench level width. Also, determination of optimum blasting bench parameters such as bore hole diameter and depth, spacing - burden ratio, sub-drilling depth, stemming length, stemming material type and size, decks type and decking length, type of explosive, column and bottom charge, powder Factor for limestone quarry at Al Ain El Sukhna - west of Gulf of Suez according to field trial tests.
\end{abstract}

\section{Introduction}

In surface mining drilling and blasting are the major unit operations and have a big effect on the materials fragmentation, safety and total production cost. Drilling and blasting cost in any quarry can reach $25 \%$ of the total production cost [1]. Bench height is important in the total quarry production cost, safety and ore dilution, so it must be assessed carefully [1]. The economical determination of bench height may vary with the machinery and equipments being used topography, capacity of drilling machine, environmental conditions, operation plans, etc. [2]. To maintain the cost at an optimum level, determining an economical bench height has to base on individual economic assessments of quarrying operation followed by the consolidation of individual assessments. Basic quarrying operations consist of drilling, blasting, loading and transportation. However, other parameters besides bench height, such as rock properties, blast hole diameter, bench geometry, type of explosives being used, etc. directly or indirectly influence the determination of the unit cost of the product. So optimization of bench height and other bench blast parameters leads to successful consequent operations such as loading and transportation from economical point of view.

\section{Calculations of vertical height of bench}

The height of bench calculation depends on some criteria such as cost, safety, 
equipment availability, ore dilution and annual schedule of production [3].

Vertical height of bench and width of bench, can be calculated according to three considerations [4].

a- $\quad$ Stability of slope faces by using Tsykovich equation.

$\mathrm{H}_{\mathrm{v}}=\frac{4 \mathrm{C}}{\gamma \operatorname{Sin} 2 \alpha}$

Fellenius modified this formula to the following form.

$\mathrm{H}_{\mathrm{v}}=0.958 \frac{4 \mathrm{C}}{\gamma}$

According to Skololovsky, the limiting height of vertical face can be determined from the formula.

$$
\mathrm{H}_{\mathrm{v}}=\frac{4 c \cos \varphi}{\gamma(1-\sin e \varphi)}
$$

Where; " $\varphi$ " is angle of repose, degrees. Also Demen suggested the following formula.

$$
\mathrm{H}_{\mathrm{v}}=\frac{\sigma c}{\gamma} \quad \sigma \mathrm{c}=2 \mathrm{c} \tan \left(45+\frac{\varphi}{2}\right)
$$

Where; "C" is cohesion, $\sigma c$ is Comperssive strength, " $\varphi$ " is the angle of repose, $\alpha$ is slope angle of slip plane, degrees.

b-The safety of the work place.

The vertical height of bench should not be greater than 1.5 times the maximum digging height of the excavator or wheel loader for safety.

$\mathrm{H}_{\mathrm{v}} \leq 1.5 \mathrm{H}_{\mathrm{dmax}}$

Where; $\mathrm{H}_{\mathrm{dmax}}$ is the maximum digging height of the excavator.

c- Efficiency of the work place.

The height of the face can be determined by the following equation.

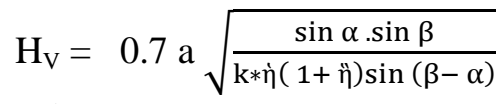

Where;

$$
\mathrm{a}=0.8\left(\mathrm{R}_{\mathrm{d}}+\mathrm{R}_{\mathrm{L}}\right)
$$

"a" is width of the broken down heap of material formed after blasting and " $\alpha$ " are slope angle of broken down material, $\mathrm{deg}, \alpha \approx 35$ for limestone.

" $\beta$ " is slope angle of the face, degree," $\mathrm{K}$ " is loosening factor of the face material values of "K" ranges from 1.3 - 1.9. "K" taken is 1.5 for limestone, " $\eta$ " is ratio of length of least resistance

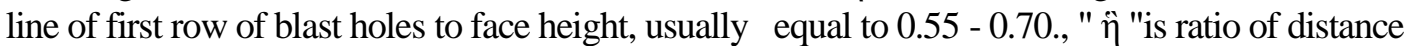
between rows of blast holes to length of line of least resistance, usually equal to $0.75-0.85$., " $R_{d}$ " is digging radius of power shovel, $\mathrm{m}$. and " $\mathrm{R}_{\mathrm{L}}$ " is loading radius of power shovel , $\mathrm{m}$. 


\section{Width of the quarry bench calculation}

The width of working bench " $\mathrm{W}_{\mathrm{L}}$ "can be calculated by the following equation.

$$
\mathrm{W}_{\mathrm{L}}=\mathrm{X}+\mathrm{C}+\mathrm{T}+\mathrm{Z}+\mathrm{M}+\mathrm{A}
$$

Where;" $\mathrm{W}_{\mathrm{L}}$ " is Bench width, " $\mathrm{C}$ " is safety distance, "T" is trucks width, " $\mathrm{Z}$ " is safety distance between the trucks and loading machines $(10 \mathrm{~m}-20 \mathrm{~m})$, " $\mathrm{M}$ "is loading machine width, "A "is burden and" $\mathrm{X}$ " is the distance between the face to the end of muck pile see figs. $(1,2)$, and can be calculating according to the following equation.

$$
\mathrm{X}=\frac{2 \mathrm{~A} \mathrm{Hb} \mathrm{ks}}{\mathrm{H}}-\mathrm{A} \mathrm{m}
$$

Where; "A" is burden, "Hb" is vertical height of bench, "Ks" is swelling factor, " $\mathrm{m}$ " is 1 for hard rock, "m" is 1.5 for medium rock and " $\mathrm{m}$ " is 2 for soft rock.

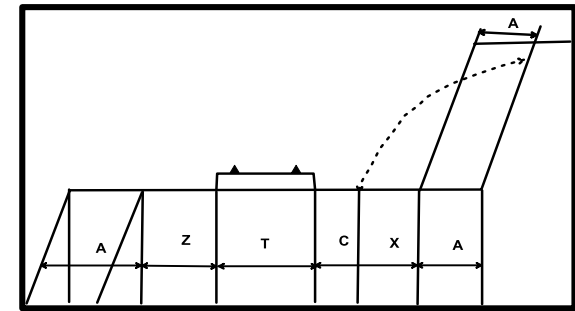

Fig. 1. Shows the bench width parts layout

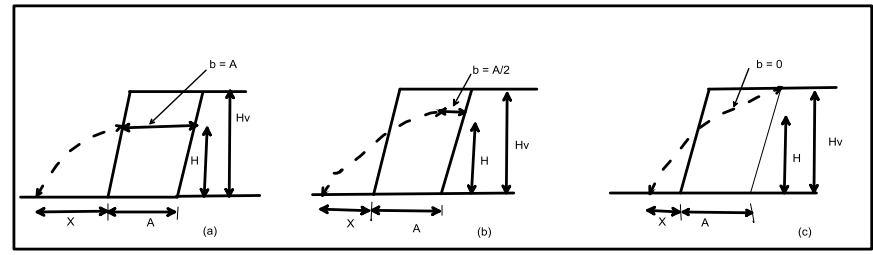

Fig. 2. Shows muck pile shape and width for (a,) for soft rock, (b) for medium rock and (c) for hard rock.

\section{Determination of the Bench Blasting Parameters}

The cost of surface mining production is Syndrome and identical with optimization of drilling and blasting. Loading, hauling and crushing costs decrease with increasing blasted rock fragmentation while drilling and blasting costs increase with increasing rock fragmentation [5]. The muck pile fragmentation size distribution is a function of the blast design parameters and the specific explosive charge of each hole [6].

Cost decreased at an optimum fragmentation size in the surface mining operation and production $[7,8]$.The back bone of the blast results quality in surface mining is the efficiency and cost of drilling \& blasting and subsequently mining unit operations such as loading, transportation and crushing operations [9].

Many formulae and methods used to calculate blasting parameters geometry (burden, spacing, and sub drilling) such as Role of thumbs, Ash, Langefors et al., and Jimeno et al. [10, 11].

Bench blasting design parameters are shown in Fig. (3), where; " D" is the diameter of blast bore hole $(\mathrm{m}), \mathrm{H}$ " is the height of bench (m), "B" the burden (m), "S" is the spacing $(\mathrm{m})$. " $\mathrm{S}_{\mathrm{D}}$ " is the sub drilling $(\mathrm{m}), \mathrm{S}_{\mathrm{T}}$ "is the stemming length of blast bore hole $(\mathrm{m})$, "L" is the length of blast hole $(\mathrm{m}), \mathrm{h}_{\mathrm{p}}$ is the column charge length $(\mathrm{m}), \mathrm{h}_{\mathrm{b}}$ "is the bottom charge length $(\mathrm{m})$. Other parameters that are taken into account in bench blasting calculations are; "I $\mathrm{p}_{\mathrm{p}}$ is the column 
charge concentration $(\mathrm{kg} / \mathrm{m}),{ }^{\prime} \mathrm{I}_{\mathrm{b}}$ "is the bottom charge concentration $(\mathrm{kg} / \mathrm{m}), \mathrm{Q}_{\mathrm{p}}$ " is the column charge weight $(\mathrm{kg}), " \mathrm{Q}$ b " is the bottom charge weight $(\mathrm{kg})$, "Q e" is the total weight of explosive charge being used in a bore hole $(\mathrm{kg}), " \mathrm{q} "$ is the powder factor $\left(\mathrm{kg} / \mathrm{m}^{3}\right)$.

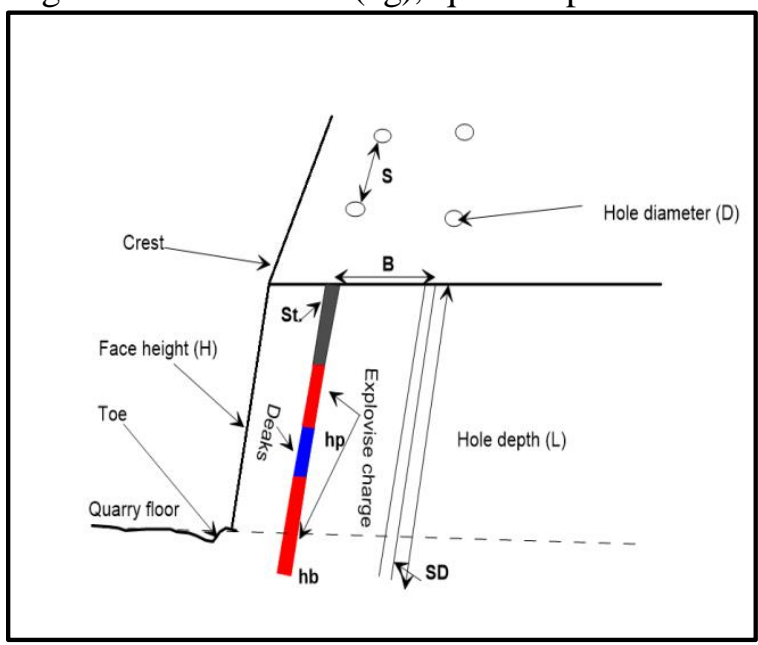

Fig. 3. shows bench blasting parameters layout

\section{Calculation of bench blast parameters}

The bench blast parameters can be calculated from the following equation according to rule of thumbs.

Burden "B "is the distance from a single row to the quarry bench face. It can be obtained from the following equation.

$$
\mathrm{B}=\mathrm{C}_{1} \mathrm{D}
$$

Where; " $\mathrm{C}_{1}$ " is constant and ranges between 25 - 40 and " $\mathrm{D}$ " is bore hole diameter.

Spacing "S" is the distance between blast holes parallel to the quarry face. Spacing is mainly a function of burden $[12,13]$. Spacing is taken from the following equation.

$\mathrm{S}=\mathrm{C}_{2} \mathrm{~B}$

Where; " $\mathrm{C}_{2}$ " is constant ranges between 1 to 1.5 .

Stemming is a specific material placed on top of explosive in the drilling bore hole. The main goal of stemming is to close the hole and go back with it to original state as much as possible in order to confine the explosion gases to reduce the blasting noise. The stemming material could be water, drill cutting, sand, mud or crushed rock. Stemming distance " $\mathrm{S}_{\mathrm{T}}$ "is depend upon bore hole diameter or burden as following.

$$
\mathrm{S}_{\mathrm{T}}=(0.7-1.0) \mathrm{B}
$$

Sub drilling is the borehole extends length below the quarry floor or the bench height and can be calculated from the following equation.

$$
\mathrm{S}_{\mathrm{D}}=(0.2-0.5) \mathrm{B}
$$

\section{Ash method for bench blast parameters calculation}

A mathematical equations for bench blast geometry parameters developed by Ash [14] and used also by many authors such as [15- 18]. 
The burden "B" is arithmetically estimated from:

$\mathrm{B}=\mathrm{K}_{\mathrm{B}} \mathrm{D}$

Where; $K_{B}=22$ in case of ANFO for rock density less than $2.7 \mathrm{~g} / \mathrm{m}^{3}$, and 30 for rock density more than $2.7 \mathrm{~g} / \mathrm{m}^{3}$, but in case of high explosive $\mathrm{K}_{\mathrm{B}}=27$ for rock density less than $2.7 \mathrm{~g} / \mathrm{m}^{3}$ and 25 for rock density more than $2.7 \mathrm{~g} / \mathrm{m}^{3}$.

Spacing "S "can calculated from the following equation.

$\mathrm{S}=\mathrm{K}_{\mathrm{s}} \mathrm{B}$

Where; " $\mathrm{K}_{\mathrm{s}}$ " is constant and it range between $1 \& 2$.

Spacing to Burden Ratio.

Spacing and burden ratio can vary between 1 and 2, when its less than 1 is not recommended $[19,20]$ because it causes premature division of the bore holes and early release of gaseous pressure and losing the contribution of gaseous energy in rock fragmentation. Spacing and burden ration more than 2 is also not recommended because it may result in incomplete breakage between the holes and poor fragmentation.

Sub drilling depth " $\mathrm{S}_{\mathrm{D}}$ " can calculated from the following equation.

$\mathrm{S}_{\mathrm{D}}=(0.2-0.5) \mathrm{B}$

The common stemming can be calculated as follow.

$\mathrm{S}_{\mathrm{T}}=(0.5-1.3) \mathrm{B}$

Stemming can be achieved when it equal 0.7 to 1.2 times the burden [21, 22]. The optimum stemming material size is $0.05-0.08$ times the bore hole diameter [16].

The spacing "S" can be calculated from the following equation.

$$
\mathrm{S}=\frac{\mathrm{H}+7 \mathrm{~B}}{8}
$$

Decks is separating two or more charges within a hole, fired at different delays. The purpose of decks is to reduce loading explosives in weak zones which is may be mud, cracks or voids. The stemming length between decks equal 6 times the bore hole diameter. The plaster stemming technique is better than the drill cuttings stemming technique because of increased locking provisions inside the hole and better utilization of blast explosive energy in the rock [23].

The bottom charge height should be equal to.

$\mathrm{h}_{\mathrm{b}}=1.3 \mathrm{~B}$

The bottom bore hole charge concentration is equal.

$$
\mathrm{I}_{\mathrm{b}}=\left(\mathrm{D}^{2} / 1000\right)(\mathrm{P} / 1.25)
$$

The bottom charge total quantity can be calculated from the following equation.

$\mathrm{Q}_{\mathrm{b}}=\mathrm{h}_{\mathrm{b}} \mathrm{I}_{\mathrm{b}}$

The column charge height can be calculated from the following equation. 
$\mathrm{h}_{\mathrm{p}}=\mathrm{H}-\mathrm{h}_{\mathrm{b}}-\left(\mathrm{S}_{\mathrm{T}}+\right.$ Decks $)$

The column charge total quantity is given as:

$\mathrm{Q}_{\mathrm{p}}=\mathrm{h}_{\mathrm{p}} \mathrm{I}_{\mathrm{p}}$

Total bore hole explosive charge being used $(\mathrm{kg})$ is given as.

$\mathrm{Q}_{\mathrm{e}}=\mathrm{Q}_{\mathrm{p}}+\mathrm{Q}_{\mathrm{b}}$

Type of explosive depends upon the rock properties of the geologic formation, waterfilled boreholes, bore hole diameter and blasting cost.

The powder factor is a relationship between the quantities of broken rocks and how much explosive is used to break it. The most common powder factor in surface mining is $0.3-0.6(\mathrm{~kg} / \mathrm{m} 3)$ but it can vary from 0.15 to $1.5(\mathrm{~kg} / \mathrm{m} 3)[24]$.

The calculation of powder factor can be derived from the following equation depending upon the rock density [25].

$$
\mathrm{q}=\mathrm{K}+\mathrm{B} \mathrm{p}
$$

Where;"q" is powder factor $\left(\mathrm{kg} / \mathrm{m}^{3}\right)$, "K", "B" are constants it's for limestone equal 0.733 and 0.400 respectively and "p" is the rock density $(\mathrm{gm} / \mathrm{cc})$. The influence of joints must be taken in consideration as introducing a correction factor as appears in the following empirical equation.

$$
\mathrm{q}_{0}=\frac{\mathrm{q}}{\mathrm{j}}
$$

Where; "q $\mathrm{q}_{0}$ is corrected powder factor by $\mathrm{kg} / \mathrm{m}^{3}$." $\mathrm{q}$ " is powder factor calculated from the previous equation and " $\mathrm{j}$ " is the correction factor depending on the block size.

Powder factor in surface mining can also calculated by knowing both of bottom and column bore hole charges from the following equation.

$$
\mathrm{q}=\frac{\mathrm{Q} \text { total }}{\mathrm{B} * \mathrm{H} * \mathrm{~S}}
$$

Where; "Q ${ }_{\text {total }}$ is total bore hole charge."B" is the burden distance."H" is the bench height " $\mathrm{S}$ " is the spacing distance.

Cost of explosive materials per cubic meter according to the blasting contactor of Egypt can be calculate by using the following formula.

$$
\text { Cost }=\frac{Q \text { total }}{q c} * \mathrm{~F}
$$

Where; $\mathrm{q}_{\mathrm{c}}$ is fixed powder factor taken as $0.3\left(\mathrm{~kg} / \mathrm{m}^{3}\right), \mathrm{F}$ is the fixed powder factor unit cost taken as 9 L.E according to explosive supplying company.

\section{Laboratory and field works}

\subsection{Rock geotechnical tests}

Four limestone samples collected from the limestone of Gabel Okheider to determine the mechanical properties of the rock. The results are summarized in table (1). 


\section{Table 1.}

Mechanical test results of Okheider limestone samples.

\begin{tabular}{|l|l|}
\hline Rock Properties & Average \\
\hline Compressive Strength $\left(\mathrm{kg} / \mathrm{cm}^{2}\right)$. & 226.7 \\
\hline Shear Stress $\left(\mathrm{kg} / \mathrm{cm}^{2}\right)$. & 39.625 \\
\hline Water Absorption $(\%)$. & 6.09 \\
\hline Dry Density $\left(\mathrm{g} / \mathrm{cm}^{3}\right)$. & 1.95 \\
\hline Wet Density $\left(\mathrm{g} / \mathrm{cm}^{3}\right)$. & 2.04 \\
\hline
\end{tabular}

\section{Field data collection and measurements}

To calculate the bench height and width we need some field measurements carried at the quarry area near the new quarry these data shown in the following table (2).

\section{Table 2.}

Field data collection and measurements.

\begin{tabular}{|l|l|}
\hline Items & Values \\
\hline Muck Pile Length (m). & 35 \\
\hline Angle of Repose (degree). & 35 \\
\hline Loader 980H Height (m). & 6 \\
\hline Loading Trucks Length (m). & 12.5 \\
\hline
\end{tabular}

\section{Trial blast at Okheider limestone quarry for bench blasting parameters determination}

Three trial blasts were performed at limestone quarry at Ain Sukhna area to select the best blasting parameters according to the field observations for the rock fragmentation of the blasted muck piles.

\section{Trial 1.}

The test has been carried with burden $4(\mathrm{~m})$, spacing $8(\mathrm{~m})$, stemming $5(\mathrm{~m})$, sub drilling $3(\mathrm{~m}), 2$ decks with $1(5 \mathrm{~m})$, length, the mass of bottom charge is $40(\mathrm{~kg})$ of dynamite and the mass of column charge is $260(\mathrm{~kg})$, of ANFO and with powder factor $234\left(\mathrm{~g} / \mathrm{m}^{3}\right)$. This trial test gave a good results of fragmentations so it was suitable for crushers without using the secondary blasting and breaking by jack hammer as it seen in Fig.(4).

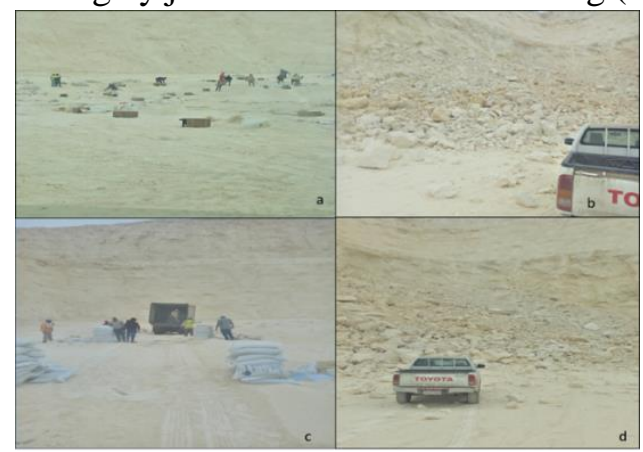

Fig. 4. Blasting trial -1 during charging and muck pile fragmentation

\section{Trial 2.}

This blasting test has been carried out with burden $7.5(\mathrm{~m})$ put as a test by the authors, spacing $9(\mathrm{~m})$, stemming $5.5(\mathrm{~m})$, sub drilling $2(\mathrm{~m})$, two decks about $2(\mathrm{~m})$, length, with mass of bottom charge $22(\mathrm{~kg})$, of dynamite, mass of column charge $328(\mathrm{~kg})$, of ANFO 
and with powder factor $128\left(\mathrm{~g} / \mathrm{m}^{3}\right)$. This trial test gave bad fragmentations as it gave a large numbers of blocks more than two meters. This leads to use secondary blasting or breaking by jack hammer gave rise of cost.as seen in Fig. (5).

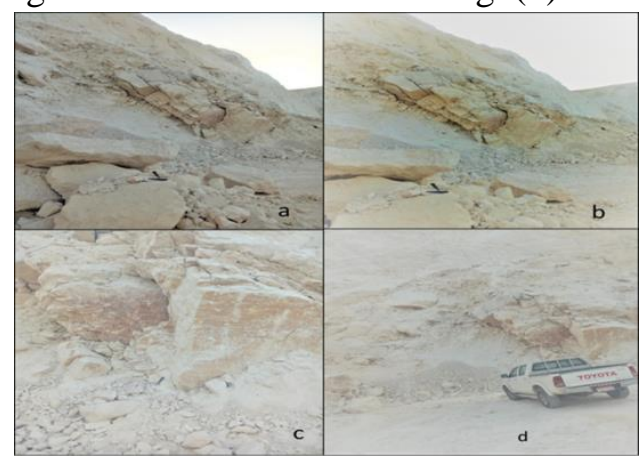

Fig. 5. Blasting trial -2 during charging and muck pile fragmentation

\section{Trial 3.}

This blasting test has been carried out with burden $4.5(\mathrm{~m})$, spacing $8(\mathrm{~m})$, stemming 5 (m), sub drilling $2.5 \mathrm{~m}$. with two decks about $2(\mathrm{~m})$, with mass of bottom charge $12(\mathrm{~kg})$, of dynamite, mass of column charge $340(\mathrm{~kg})$, of ANFO and with powder factor 305 $\left(\mathrm{g} / \mathrm{m}^{3}\right)$, the fragmentation are extremely fine as it seen in Fig. (6). This leads to clogging in crusher. Fig. (7), explains the charge methods for the test trails.

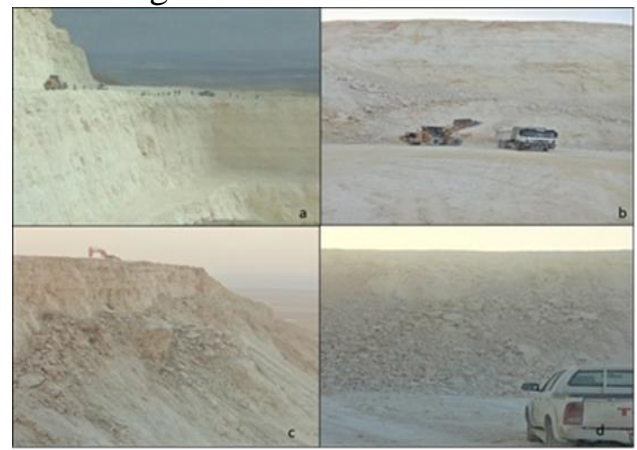

Fig. 6. Blasting trial -3 during charging and muck pile fragmentation

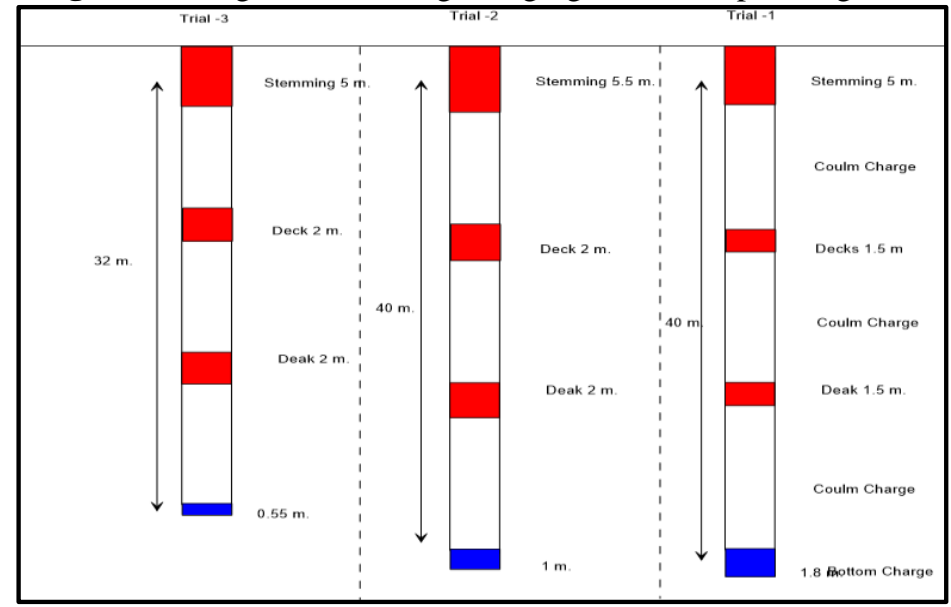

Fig.7. Explains the charge methods for the test trails. 


\section{Results}

The bench height of Okheider limestone quarry due to stability of the face slope equal 115 $\mathrm{m}$. this means that quarry face can reach $115 \mathrm{~m}$. from the point of view of face stability.

The height of bench according to safety of working place equal $9.75 \mathrm{~m}$.

The bench height calculation of Okheider limestone quarry is $16.8 \mathrm{~m}$. after calculation from equation no. 6 due to the efficiency of working place.

The bench width at the studied quarry equals $39.9 \mathrm{~m}$. when using available Caterpillar wheel loader $980 \mathrm{H}$ type.

The aim of this study is to reach to a good blasting fragmentation of muck pile suitable for crusher feeding with low cost so the powder factor Calculation using rock density equation is too high and will increase the total blasting cost for Okheider limestone.

Calculation of the blasting design parameters using Rule of thumb and Ash approaches produced the results in Table (4). These results from the two different methods of determination processes were very different from each other.

Determination of bench blasting parameters of three blasting trial field tests results are presented in Table (4), the trials have been carried out at different bench heights and with different powder factors.

\section{Table 4.}

summary of blasting design parameters results of empirical blasting equations and three trial blasting tests.

\begin{tabular}{|c|c|c|c|c|c|}
\hline Parameter s & $\begin{array}{l}\text { Rule of } \\
\text { Thumbs } \\
\text { Methods }\end{array}$ & $\begin{array}{c}\text { Ash } \\
\text { Methods }\end{array}$ & Trial no. 1 & $\begin{array}{c}\text { Trial no. } \\
2\end{array}$ & $\begin{array}{c}\text { Trial no. } \\
3\end{array}$ \\
\hline Bench Height (m). & 40 & 40 & 40 & 40 & 32 \\
\hline Bore Hole Diameter (mm). & 152 & 152 & 152 & 152 & 152 \\
\hline Burden (m). & 4.6 & 3.3 & 4 & 7.5 & 4.5 \\
\hline Spacing $(\mathrm{m})$. & 5.7 & 5 & 8 & 9 & 8 \\
\hline Spacing / Burden Ratio. & 1.2 & 1.5 & 2 & 1.2 & 1.78 \\
\hline Sub Drilling (m). & 1.4 & 1 & 3 & 2 & 2.5 \\
\hline Bore Hole Depth $(\mathrm{m})$. & 41.4 & 41 & 43 & 42 & 34.5 \\
\hline Stemming $(\mathrm{m})$. & 6.8 & 3 & 5 & 5.5 & 5 \\
\hline StemmingMaterials Size (mm). & $0.065-2$ & $0.065-2$ & $0.065-2$ & $0.065-2$ & $0.065-2$ \\
\hline Depth and number of Decking ( $m$ *no.). & - & - & $1.5 * 2$ & $2 * 2$ & $2 * 2$ \\
\hline Charge Length (m). & 34.5 & 38 & 35 & 32.5 & 24.5 \\
\hline Type of Explosive. & $\begin{array}{l}\text { G.Dyt \& } \\
\text { ANFO }\end{array}$ & $\begin{array}{l}\text { G.Dyt \& } \\
\text { ANFO }\end{array}$ & $\begin{array}{c}\text { G. Dyt. \& } \\
\text { ANFO }\end{array}$ & $\begin{array}{c}\text { G. Dyt \& } \\
\text { ANFO }\end{array}$ & $\begin{array}{l}\text { G. Dyt. \& } \\
\text { ANFO }\end{array}$ \\
\hline Bottom charge length $(\mathrm{m})$. & 6 & 4.3 & 1.8 & 1 & 0.55 \\
\hline Blast Hole Bottom charge weight $(\mathrm{kg})$. & 109 & 80.3 & 40 & 22 & 12 \\
\hline Blast Hole Column charge length $(\mathrm{m})$. & 27.2 & 32.7 & 33.2 & 31.5 & 22.95 \\
\hline Blast Hole Column Charge weight (kg). & 503 & 604 & 280 & 328 & 340 \\
\hline Blast Hole Total charge / hole $(\mathrm{kg})$. & 612 & 684.3 & 320 & 350 & 352 \\
\hline Rock Volume. $\left(\mathrm{m}^{3}\right) /$ Hole. & 1048.8 & 660 & 1280 & 2700 & 1152 \\
\hline Powder Factor $\left(\mathrm{g} / \mathrm{m}^{3}\right)$. & 580 & 1004 & 250 & 128 & 305 \\
\hline Fragmentations. & Unsuitable & Unsuitable & Suitable & Unsuitable & Unsuitable \\
\hline $\operatorname{Cost}\left(\mathrm{LE} / \mathrm{m}^{3}\right)$. & 17.74 & 30.12 & 7.5 & 3.84 & 9.15 \\
\hline
\end{tabular}

\section{Conclusion}

According to the vertical height of bench calculations, the bench height of Okheider limestone quarry equals to $115 \mathrm{~m}$, is save but it is not applicable due to expected difficult drilling process and poor fragmentation. The vertical height of benches $16.8 \mathrm{~m}$. and 9.75 
$\mathrm{m}$, have problem in the total quarry production and cost. Okheider limestone quarry will be designed to produce around 5-6 million tons annually. So from the economic point of view the selected height of bench is taken between $30-40 \mathrm{~m}$, to verify the target of quarry production, the determining width of bench is taken as $40 \mathrm{~m}$.

According to field observations (fragmentation and cost calculations) the author found that Rule of thumbs and Ash bench blast parameters calculation methods are not suitable due to very high cost per cubic meter. The author has found that trial-1test has the best values of bench blast design parameters for the limestone quarry at Gable Okheider due to low cost and good fragmentations. So, due to the variation of rock formation properties of Okheider limestone quarry compared to the formation in the selected empirical equations, some modifications have to make to these equations. The authors suggest that these relationships become as the follow.

$$
\begin{gathered}
\mathrm{B}=0.026 \mathrm{D} \\
\mathrm{B}=\mathrm{H} / 10 \\
\mathrm{~S}=2 \mathrm{~B} \\
\mathrm{~S}_{\mathrm{T}}=1.2 \mathrm{~B} \\
\mathrm{~S}_{\mathrm{D}}=0.75 \mathrm{~B}
\end{gathered}
$$

Where; "B" is the burden in $\mathrm{m}, " \mathrm{H}$ " is the bench height in $\mathrm{m}$, and" $\mathrm{D}$ "is hole diameter in $\mathrm{mm}$.

\section{REFERENCES}

[1] Roman, P.A and Daneshmend, L .2000. Economies of Scale In Mining- Assessing Upper Bounds With Simulation, The Engineering Economist: J. Devot. Problems Capital Invest. vol.45 (4) pp. 326-338.

[2] Hustrulid, W. and Kuchta, M. 1998.Open Pit Mine Planning and Design, vol.1 Fundamentals. Balkema. Rotterdam pp. 257.

[3] Hossein, S., Morteza, O., Ali S. and Shahnam B.M., 2010. Selection of Practical Bench Height in open Pit Mining Using A multi-Criteria Decision Making Solution, Journal of Geology and Mining Research vol. 2 (3) pp. 48-59.

[4] Melnikov, M. C. 1969. Safety in Open Cast Mining, Handbook, Mir Publishers, Moscow, pp.129-142.

[5] Engin I. C. 2010. A practical method of bench blasting design for desired fragmentation based on digital image processing technique and Kuz-Ram model. Taylor \& Francis Group, London, vol. 1 ISBN 978-0-415-48296, pp. 257-263

[6] Ouchterlony F., Sanchidria'n J.A, Moser P. 2017. Percentile fragment size predictions for blasted rock and the fragmentation-energy fan. Rock Mech Rock Eng vol.50 (4), pp.751779.

[7] Mackenzie, A.S. 1967. Optimum blasting. Proc. $28^{\text {th }}$ Annual Minnesota Mining Symp., Duluth, MN, pp. 181- 188 .

[8] Morin, M.A. \& Ficarazzo F. 2006. Monte Carlo simulation as a tool to predict blasting fragmentation based on the Kuz-Ram model. Computers \& Geosciences. vol. 32 (3), pp. $352-359$.

[9] Victor M. B., 2015. Optimization of Blasting Design Parameters on Open Pit Bench a Case Study of Nchanga Open Pits, international journal of scientific \& technology research vol. 4, issue 09, pp. 45-51

[10] Langefors, U. and Kihlström, B. 1976. The Modern Technique of Rock Blasting, 3rd edition. New York: John Wiley and Sons. pp. 405. 
JES, Assiut University, Faculty of Engineering, Vol. 48, No. 1, January 2020, pp. 54-64

[11] Jimeno, C.L., Jimeno, E.L. and Carcedo, F.J.A. 1995. Drilling and Blasting of Rocks. Rotterdam: Balkema. pp. 160-180.

[12] Pugliese, J.M. 1972. Designing Blast Patterns Using Empirical Formulas- A comparison of calculated patterns of plan used in quarrying limestone and dolomite with geologic consideration USBM-IC 8550. pp. 33

[13] Gergory, C. E., 1984. Explosives for North American Engineer" 3nd Edition. Transaction Technology Publications, Clausthal -Zellerfeld, Germany.

[14] Ash, R.L. 1963b.The mechanics of rock breakage, standards for blasting design. Pit and Quarry vol. 56 (3).pp 118-122.

[15] Wyllie, D.C. and Mah, C.W. 2005. Rock Slope Engineering, Civil and Mining, 4th edition. New York: Spon Press, pp. 245-275

[16] KonyaC.J. and Walter, E.J. 1990. Surface Blast Design. Englewood Cliffs, New Jersey: Prentice Hall Publishing. pp. 114-133.

[17] Anderson, O. 1952. Blast Hole Burden Design Proc Aus I MM, No 166-7, pp. 166-167

[18] Vutukuri, V.S. and Bhandari, S. 1973. Some aspects of design of open pit blasts. Nat. Symp. Rock Fragmentation, Adelaide, pp 57-61.

[19] Fraenkel, K.H. 1952. Factors influencing blasting results, Manual of Rock Blasting (Stockholm, Aktiebolaget Atlas Diesel), vol I, Art 6, No 2, p 15

[20] Pugliese, J.M. 1972. Designing Blast Patterns Using Empirical Formulas, USBM-IC 8550.

[21] Kanchibotla, S.S., 2001. Optimum blasting? Is it Minimum Cost per Broken Rock or Maximum Value per Broken Rock? Proc. Explo-2001, NSW, AusIMM. pp. 35-40.

[22] Adhikari, G. R., Barman B. K. and Singh B., 1990. Control of Fines through Blasting Design at a Limestone Quarry, Mining Science and Technology, vol.11 pp. 173-177.

[23] Cevizci H., 2012. A newly developed plaster stemming method for blasting, the journal of the southern African institute of mining and metallurgy. vol. 112, pp. 1071-1078.

[24] Ash, R. L., 1990, Design of Blasting Rounds in Surface Mining, 2nd Edition, B.A. Kennedy, ed., SME, pp. 565-583.

[25] Muftuoglu, Y.V., Pasamehmetoglu, A.G. and Karpuz, C. 1991. Correlation of Powder Factor with Physical Properties and Rotary Drill Performance in Turkish surface Coal Mines. 7th Int. Cong. on Rock Mechanics, Aachen, Germany, A.A. Balkema, pp. 10491051.Blasting, Brisbane, Australia, 26-31 Aug., pp. 303-309.

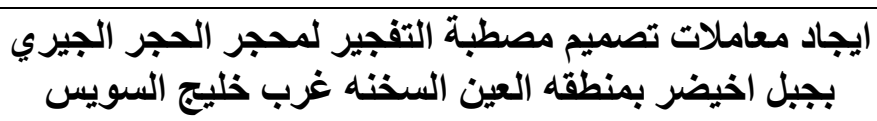

العناصر الهندسية لتصميم مصطبة التفجير تعتبر من اهم المر احل لاستخر اج الصخور ـ هذه العناصر لها تأتئير

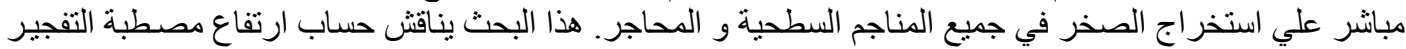

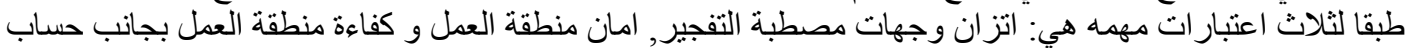

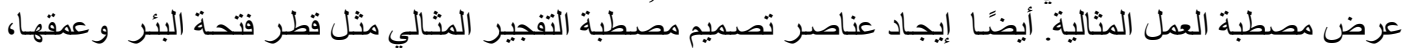

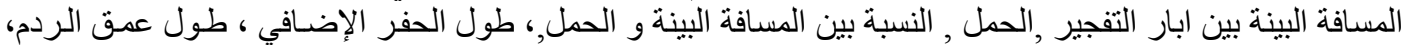

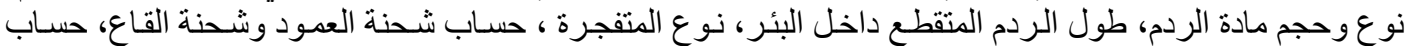

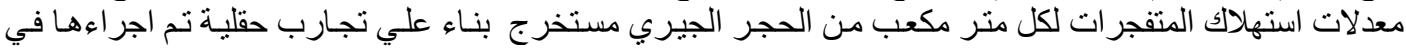
محجر الحجر الجيري بمنطقة العين السخنة غرب العزب خليج السويس مصر. 